\title{
OMNIBUS LAW DAN IZIN LINGKUNGAN DALAM KONTEKS PEMBANGUNAN BERKELANJUTAN
}

\author{
(Omnibus Law and Environmental Permit in The Context Of Sustainable Development)
}

\author{
AL Sentot Sudarwanto dan \\ Fakultas Hukum Universitas Sebelas Maret Surakarta \\ JI. Ir. Sutami No. 36 A, Kentingan Surakarta, 57126 \\ e-mail: alsentotsudarwanto@staff.uns.ac.id \\ Dona Budi Kharisma \\ Fakultas Hukum Universitas Sebelas Maret Surakarta \\ Jl. Ir. Sutami No. 36 A, Kentingan Surakarta, 57126 \\ e-mail: donabudikharisma@staff.uns.ac.id
}

Naskah diterima: 24 Februari 2020; revisi: 1 April 2020; disetujui: 6 April 2020

\begin{abstract}
Abstrak
Masalah perizinan menjadi salah satu masalah terkait investasi yang perlu dibenahi. Oleh karenanya, Pemerintah melalui Omnibus Law melakukan penyederhanaan perizinan. Salah satu bentuk penyederhanaan perizinan yaitu dengan penghapusan izin lingkungan. Upaya tersebut tentunya bertentangan dengan Tujuan Pembangunan Berkelanjutan. Disatu sisi, polusi dan kerusakan lingkungan masih menjadi salah satu masalah dan tantangan besar Indonesia yang belum bisa terselesaikan saat ini. Merespon permasalahan tersebut, penelitian ini berusaha untuk menganalisis korelasi antara izin lingkungan dengan tujuan pembangunan berkelanjutan. Artikel ini juga akan menganalisis mengapa subtansi izin lingkungan dalam Omnibus Law bertentangan dengan tujuan pembangunan berkelanjutan. Jenis penelitian ini adalah penelitian hukum normatif. Teknik pengumpulan data dilakukan dengan studi literature dan observasi dokumen. Teknik analisis yang digunakan adalah analisis yuridis kualitatif. Hasil penelitian menyimpulkan bahwa izin lingkungan adalah wujud integrasi antara dimensi sosial, ekonomi dan lingkungan dalam konteks Tujuan Pembangunan Berkelanjutan. Omnibus Law harus dapat menyederhanakan izin usaha dengan tetap memperhatikan lingkungan hidup. Penelitian ini merekomendasikan kepada Pemerintah untuk tetap menerapkan izin lingkungan dalam subtansi Omnibus Law. Di dalam Omnibus Law perlu dikonstruksikan proses perizinan lingkungan yang cepat, sederhana dan biaya yang memadai melalui rekonstruksi kelembagaan, konsistensi mekanisme penilaian izin lingkungan, dan penambahan Pejabat Pengawas Lingkungan Hidup Daerah (PPLHD).
\end{abstract}

Kata Kunci: omnibus law, izin lingkungan, pembangunan berkelanjutan

\begin{abstract}
One of issues related to investment that needs to be addressed is issue in license/permit. Therefore, the government through Omnibus Law try to simplify this, such as removing environmental permit. This effort consider to conflict with the Sustainable Development Goals, while pollution and environmental damage is still one of Indonesia's major problems. This research try to seek correlation between environmental permits and the SDGs along with why the substance of environmental permits in the Omnibus Law is contrary to the SDGs. This research is a normative legal research, with literature and documents studies which is analize using qualitative juridical analysis. The research shows that environmental permit is a form of integration between social, economic and environmental dimensions in the context of the SDGs. The Omnibus Law must be able to simplify business permit yet consider the environment issues. The government must continue to insert environmental permits as substance in Omnibus Law. The Omnibus Law has to construct a fast, simple and adequate cost of environmental permit processes through institutional reconstruction, consistency in the evaluation environmental permits, and the addition of a Regional Environmental Oversight Officer.
\end{abstract}

Keywords: omnibus law, environmental permissions, sustainable development 


\section{A. Pendahuluan}

Pada akhir tahun 2019 hingga saat ini, Omnibus Law menjadi isu hukum yang menarik untuk diperbincangkan. Tidak hanya para ahli hukum, para ekonom, politisi, masyarakat, LSM bahkan aktivis lingkungan pun turut mengkritisi spirit Presiden Jokowi untuk menyederhanakan regulasi yang ada saat ini melalui Omnibus Law. Hal itu lantaran, timbul pertanyaan dikalangan masyarakat apakah Omnibus Law dapat menjadi "obat" yang tepat untuk meningkatkan iklim investasi dan mengatasi problematika UMKM saat ini? Atau justru menempatkan pelaku usaha pada ketidakpastian berusaha dan memperlemah Pemerintah dalam pengawasan kegiatan usaha. Tampaknya masih membutuhkan kajian komprehensif untuk membuktikan korelasi positif antara Omnibus Law dengan iklim investasi.

Penyederhanaan perizinan melalui Rancangan Undang-Undang Omnibus Law Cipta Lapangan Kerja adalah respon cepat pemerintah untuk menyikapi kondisi dimana pelaksanaan kegiatan usaha saat ini menggunakan pendekatan izin (license approach) tanpa pendekatan risiko (RiskBased Approach/RBA). Kondisi ini memberikan konsekuensi bahwa seluruh kegiatan usaha harus memiliki izin. Akibatnya, untuk beberapa sektor tertentu memang memerlukan banyak izin yang harus dimiliki oleh pelaku usaha sebelum menjalankan usahanya. Sektor Migas misalnya, memerlukan 373 izin dan sektor Pembangkit Tenaga Listrik (IPP) memerlukan 29 izin. $^{1}$

Masalah perizinan memang menjadi salah satu masalah terkait investasi yang perlu dibenahi selain persyaratan investasi, ketenagakerjaan, kemudahan dan perlindungan UMKM dan kemudahan berusaha. ${ }^{2}$ Belum lagi, dari aspek regulasi, kondisi obesitas regulasi dan tumpang tindih regulasi yang mengatur mengenai investasi dan UMKM di Indonesia berakibat pada terhambatnya iklim investasi dan pertumbuhan ekonomi.

Saat ini regulasi mengenai UMKM tersebar dalam berbagai peraturan perundangundangan, sehingga berimplikasi pada sistem pemberdayaan UMKM yang terpecah, tidak komprehensif, dan menghambat investasi. Regulasi tersebut antara lain prosedur dan biaya perizinan memulai usaha, syarat kepemilikan saham minoritas, dan pelayanan melalui sistem online. ${ }^{3}$ Kondisi ini tentunya bertolak belakang dengan prinsip kemudahan berusaha yang sedang diusung pemerintah. Selain itu, belum adanya standar usaha yang ditetapkan Pemerintah untuk melakukan suatu usaha juga menjadi barrier pelaku usaha saat ini.

Mengatasi hal tersebut, berbagai regulasi terkait izin usaha, syarat investasi, tenaga kerja, dan pajak menjadi contoh regulasi yang perlu dibenahi. Ditambah lagi berbagai regulasi di tingkat daerah yang terkadang

\footnotetext{
Kementrian Lingkungan Hidup dan Kehutanan, "Bahan Rapat Terbatas Omnibus Law Cipta Lapangan Kerja", Bogor, 27 Desember 2019.

2 Sulasi Rongiyati, "Menata Regulasi Pemberdayaan UMKM Melalui Omnibus Law", Info Singkat (Kajian Singkat Terhadap Isu Aktual Dan Strategis), Vol. XI, No.23 (2019), http://berkas.dpr.go.id/puslit/files/info_singkat/ Info\%20Singkat-XI-23-I-P3DI-Desember-2019-195.pdf (diakses pada 14 Februari 2020).

3 Ade Irawan Taufik, "Evaluasi Regulasi dalam Menciptakan Kemudahan Berusaha bagi UMKM", Jurnal Rechtvinding Vol. 6, No. 3 (2017): 371.
} 
justru bertentangan dengan regulasi ditingkat pusat. Artinya, diperlukan terobosan kebijakan pemerintah untuk mengatasi kondisi tersebut. Salah satu upaya berani yang dilakukan pemerintah yaitu mengusulkan RUU Omnibus Law Cipta Lapangan Kerja.

Arah baru pembangunan lingkungan turut mewarnai Omnibus Law yang sedang diusung pemerintah. Penghapusan Izin Mendirikan Bangunan (IMB) dan Analisis Mengenai Dampak Lingkungan (AMDAL) sebagai instrumen lingkungan hidup menjadi isu lingkungan yang menarik untuk dikaji. Langkah tersebut diklaim sebagai bentuk penyederhanaan izin yang diharapkan dapat memudahkan investasi tanpa mengorbankan kualitas penataan ruang dan kualitas lingkungan.

Disatu sisi, permasalahan lingkungan masih menjadi permasalahan yang belum bisa terselesaikan sampai dengan saat ini. Polusi lingkungan dan kerusakan lingkungan menjadi ancaman dan tantangan besar Pemerintah Indonesia dibidang Lingkungan Hidup. ${ }^{4}$ Tumbuhnya permasalahan-permasalahan Bahan Berbahaya dan Beracun (B3) dan limbah B3 pada periode 2015-2018 tergolong cepat dan beragam. Setidaknya jika dilihat dari masalah-masalah yang muncul ke permukaan seperti tidak tertanganinya limbah medis, slag aluminium, kontaminasi penimbunan Limbah Bahan Berbahaya dan Beracun (LB3) ke permukiman warga, kontaminasi merkuri dan sianida di berbagai lokasi pertambangan rakyat dan lain-lain. ${ }^{5}$ Sebagai upaya untuk mengatasi berbagai permasalahan tersebut, Pemerintah telah melakukan berbagai upaya, diantaranya pembangunan dan perbaikan infrastruktur limbah, memperketat pengawasan dan pembinaan pelaku usaha serta mengeluarkan berbagai paket kebijakan dan regulasi terkait pengelolaan lingkungan hidup.

Isu lingkungan juga menjadi salah satu sasaran dalam Sustainable Development Goals (Tujuan Pembangunan Berkelanjutan) ${ }^{6}$ yang mendesak untuk diselesaikan baik di negara maju ataupun di negara berkembang. Inti dalam pembangunan berkelanjutan adalah untuk mencapai pertumbuhan ekonomi yang berkualitas, pemerintah meningkatkan intensitas pelaksanaan pembangunan yang inklusif dan berkelanjutan, dengan lebih memperhatikan aspek lingkungan.

Namun, izin lingkungan yang seharusnya diberlakukan sebagai langkah pencegahan terhadap dampak pencemaran dan kerusakan lingkungan justru dihapuskan dalam substansi Omnibus Law. Bahkan, AMDAL sebagai suatu kajian mengenai dampak penting suatu usaha dan/atau kegiatan yang direncanakan pada lingkungan hidup, yang diperlukan bagi proses pengambilan keputusan tentang penyelenggaraan usaha dan/atau kegiatan juga dihapuskan. Merespon problematika tersebut, artikel ini berusaha untuk menganalisis korelasi antara izin lingkungan dengan Tujuan Pembangunan Berkelanjutan

4 Asian Environmental Compliance and Enforcement Network, "Environmental Compliance and Enforcement in Indonesia Rapid Assessment", (The Secretariat of Asian Environmental Compliance and Enforcement Network, 2008), hlm. 6.

$5 \quad$ Indonesian Center for Environmental Law (ICEL), "Catatan Awal Tahun 2019: Narasi Yang Hilang Dalam Proyeksi Kebijakan Lingkungan Hidup Capres-Cawapres", (ICEL , 2019). hlm. 19-20.

6 Mickael B. Hoelman et all, Panduan SDGs Untuk Pemerintah Daerah (Kota dan Kabupaten), (Jakarta: International NGO Forum on Indonesian Development, 2015). hlm. 8. 
(Sustainable Development Goals). Selain itu, dalam artikel ini juga akan dianalisis mengapa subtansi izin lingkungan dalam Omnibus Law bertentangan dengan Tujuan Pembangunan Berkelanjutan (Sustainable Development Goals).

Berdasarkan uraian latar belakang tersebut di atas, rumusan permasalahan dalam artikel ini dapat dirumuskan sebagai berikut bagaimanakah korelasi antara izin lingkungan dengan konsep pembangunan berkelanjutan (Sustainable Development Goals) dan mengapa konsep perizinan usaha dalam RUU Omnibus Law Cipta Lapangan Kerja bertentangan dengan konsep pembangunan berkelanjutan (Sustainable Development Goals).

\section{B. Metode Penelitian}

Jenis penelitian ini adalah penelitian hukum normatif. Beberapa pijakan yuridis yang digunakan dalam penelitian ini adalah Undang-Undang No. 32 Tahun 2009 tentang Perlindungan dan Pengelolaan Lingkungan Hidup, Peraturan Pemerintah No. 27 Tahun 2012 tentang Izin Lingkungan, Peraturan Pemerintah No. 24 Tahun 2018 tentang Pelayanan Perizinan Berusaha Terintegrasi Secara Elektronik, Peraturan Presiden No. 59 Tahun 2017 tentang Pelaksanaan Pencapaian Tujuan Pembangunan Berkelanjutan, Instruksi Presiden No. 7 Tahun 2019 Tentang Percepatan Kemudahan Berusaha, Peraturan Menteri Lingkungan Hidup Nomor 16 Tahun 2012 tentang Pedoman Penyusunan Dokumen Lingkungan Hidup, Peraturan Menteri Lingkungan Hidup Dan Kehutanan No. P.24/ MENLHK/SETJEN/KUM.1/7/2018 tentang Pengecualian Kewajiban Menyusun Analisis Mengenai Dampak Lingkungan untuk Usaha dan/atau Kegiatan yang Berlokasi di Daerah Kabupaten/Kota yang telah memiliki Rencana Detail Tata Ruang (RDTR), Peraturan Menteri Agraria Dan Tata Ruang/Kepala Badan Pertanahan Nasional Republik Indonesia No. 16 Tahun 2018 Tentang Pedoman Penyusunan Rencana Detail Tata Ruang dan Peraturan Zonasi Kabupaten/Kota dan berbagai regulasi yang terkait dengan lingkiungan hidup.

Teknikpengumpulan data dilakukan dengan studi literature dan observasi dokumen. Sifat penelitian ini adalah penelitian deskriptif yang bertujuan untuk mendiskripsikan secara sistematis, faktual, dan akurat terhadap suatu populasi atau daerah tertentu, mengenai sifat-sifat, karakteristik atau faktor-faktor tertentu. Analisis yang digunakan adalah analisis yuridis kualitatif, yaitu analisis berdasarkan interpretasi hukum, penalaran hukum, dan argumentasi hukum. Penelitian ini mendekripsikan mengenai artikel ini berusaha untuk menganalisis korelasi antara Izin Lingkungan dengan Tujuan Pembangunan Berkelanjutan (Sustainable Development Goals). Selain itu, dalam artikel ini juga akan menganalisis mengapa subtansi Izin Lingkungan dalam Omnibus Law bertentangan dengan Tujuan Pembangunan Berkelanjutan (Sustainable Development Goals).

\section{Pembahasan}

\section{Korelasi Izin Lingkungan Dengan Tujuan Pembangunan Berkelanjutan (Sustainable Development Goals)}

\section{a. Konsep Pembangunan Berkelanjutan (Sustainable Development Goals)}

Konsep pembangunan berkelanjutan timbul ketika pengelolaan lingkungan hidup berorientasi pada kepentingan ekonomi atau juga dapat dikatakan antroposentris 
maka akan cenderung pada usaha-usaha atau kegiatan-kegiatan yang eksploitatif terhadap lingkungan hidup. Untuk memenuhi kepentingannya, seringkali manusia cenderung melakukan dosa-dosa terhadap lingkungan hidup (environmental sins). ${ }^{7}$ Oleh karenanya, setiap pembangunan ekonomi yang dilakukan perlu mempertimbangkan dampak terhadap lingkungan, sehingga perlu dikembangkan dan diimplementasikan pola pembangunan berwawasan lingkungan.

Pembangunan berwawasan lingkungan merupakan usaha meningkatkan kualitas manusia secara bertahap dengan memperhatikan faktor lingkungan, yang mengoptimalkan manfaat sumber daya alam dan sumber daya manusia dengan cara menserasikan aktivitas manusia dengan kemampuan sumber daya alam untuk menopangnya. Pembangunan berwawasan lingkungan dikenal dengan nama pembangunan berkelanjutan (sustainable development). ${ }^{8}$

Strategi pembangunan dalam SDG's, bertumpu pada 4 track development strategy. Keempat strategi itu adalah: (a) meningkatkan laju pertumbuhan ekonomi yang tinggi dan berkualitas (pro-growth); (b) menciptakan dan memperluas lapangan kerja (pro-job); (c) meningkatkan kesejahteraan rakyat melalui program-program jaring pengaman sosial yang berpihak kepada masyarakat miskin (pro-poor); dan (d) meningkatkan kualitas pengelolaan lingkungan hidup (proenvironment). ${ }^{9}$

Di Indonesia, Tujuan Pembangunan berkelanjutan sudah memiliki payung hukum yang tegas yaitu diatur dalam Peraturan Presiden No. 59 Tahun 2017 tentang Pelaksanaan Pencapaian Tujuan Pembangunan Berkelanjutan. Peraturan tersebut adalah wujud komitmen pemerintah yang digunakan sebagai acuan bagi Pemerintah Pusat, Pemerintah Daerah, Swasta, Lembaga Swadaya Masyarakat dan masyarakat dalam pelaksanaan pencapaian SDG's.

Konsep pembangunan berkelanjutan menempatkan pembangunan dalam perspektif jangka panjang (a longer term perspective). Konsep tersebut menuntut adanya solidaritas antar generasi. ${ }^{10}$ Dalam ketentuan umum Undang-Undang Nomor 32 Tahun 2009 tentang Perlindungan dan Pengelolaan Lingkungan Hidup (UndangUndang UPPLH), pembangunan berkelanjutan adalah upaya sadar dan terencana yang memadukan aspek lingkungan hidup, sosial, dan ekonomi ke dalam strategi pembangunan untuk menjamin keutuhan lingkungan hidup serta keselamatan, kemampuan, kesejahteraan, dan mutu hidup generasi masa kini dan generasi masa depan.

Secara mendasar, Undang-Undang PPLH mempunyai idealisme mengaplikasikan isu-isu lingkungan hidup kedalam nilai-nilai ekonomis. Gunanya adalah untuk meningkatkan

7 Eko Budiardjo dan Sudanti Hardjohubojo, Kota Berwawasan Lingkungan (Bandung: Alumni,1993). hlm. 146147.

8 AL. Sentot Sudarwanto, AMDAL \& Proses Penyusunan (Berdasarkan Peraturan Menteri Lingkungan Hidup Nomor 16 Tahun 2012 Tentang Pedoman Penyusunan Dokumen Lingkungan Hidup) (Surakarta: UNS Press, 2018), hlm. 2.

9 Armida Salsiah Alisjahbana, "Strategi indonesia Mewujudkan Pembangunan Berkelanjutan, Inklusif, dan Berkeadilan", Konferensi INFID Jakarta, 27 November 2013.

10 Sudharto P Hadi, Dimensi Lingkungan Perencanaan Pembangunan (Yogyakarta: Gadjah Mada Ubiversity Press.,2001), hlm. 2. 
kesadaran akan pentingnya keberlanjutan sumber daya alam dan meningkatkan kualitas lingkungan. Hal demikian pada akhirnya akan mempengaruhi pula pertumbuhan ekonomi. Lebih lanjut, hukum yang mengatur tentang segi-segi lingkungan hidup haruslah bersifat antisipatif. Hal tersebut tercermin dari pernyataan "untuk menjamin kemampuan, kesejahteraan dan mutu hidup generasi masa mendatang. ${ }^{11}$

Beberapa formula strategis konsep pembangunan berkelanjutan diterapkan dalam konteks negara-negara berkembang seperti Indonesia adalah sebagai berikut: ${ }^{12}$ Pertama, Pembangunan berkelanjutan menghendaki penerapan perencanaan tata ruang (spatial planning) misalnya pembangunan sumber daya alam yang memperhatikan daya dukung lingkungan. Penempatan berbagai macam aktivitas yang menggunakan sumber daya alam harus memperhatikan kapasitas lingkungan alam yang mengadsorbsi perubahan yang diakibatkan oleh aktivitas pembangunan. Untuk itu sumber daya alam di suatu negara sebaiknya dibagi kedalam sumber daya alam yang harus dikonservasi dan dilindungi dan sumber daya alam yang bisa dieksploitasi. Sumber daya alam dialokasikan dalam beberapa zona seperti zona industri, zona suaka alam, daerah aliran sungai, zona perumahan, zona perdagangan, zona taman nasional, zona perkebunan dan sebagainya. Perencanaan regional harus mendasarkan zona-zona di atas yang memasukkan muatan lingkungan di dalamnya.
Kedua, Perencanaan pembangunan menghendaki adanya standar lingkungan seperti standar ambien untuk air permukaan, air bawah tanah, air laut dan udara di kota dan daerah pedesaan. Dengan adanya standar kegiatan industri tidak diizinkan untuk membuang limbah melebihi baku mutu. Dengan standar itu pula, kaulitas lingkungan akan bisa lebih terjamin.

Ketiga, Penerapan Analisis Mengenai Dampak Lingkungan (AMDAL). Setiap rencana usaha dan/atau kegiatan yang diperkirakan menimbulkan dampak penting terhadap lingkungan harus dilengkapi dengan studi AMDAL. Setelah dampak diidentifikasi, diprakirakan dan di evaluasi maka langkah selanjutnya adalah bagamana tersebut dikelola dan dipantau. Dengan adanya AMDAL maka setiap rencana usaha dan/atau kegiatan tidak hanya layak secara ekonomis dan teknologis tetapi juga layak secara lingkungan.

Keempat, Rehabilitasi kerusakan lingkungan khususnya di daerah kritis seperti sungai-sungai yang menjadi tempat pembuangan dan di lahan kritis. Kelima, Usaha untuk memasukkan pertimbangan lingkungan kedalam perhitungan ekonomi sebagai dasar untuk kebijakan ekonomi lingkungan.

Hakikat pembangunan berwawasan lingkungan yaitu pembangunan yang didasarkan pada tiga pertimbangan secara proporsional yaitu pertimbangan ekonomi, pertimbangan sosial dan pertimbangan ekologi. Pokok-pokok arahan kebijaksanaan dibidang sumber daya alam dan lingkungan hidup dalam pembangunan berwawasan 
lingkungan adalah: ${ }^{13}$ a. Inventarisasi sumber daya alam, b. Pemanfaatan teknologi yang memadai, c. Menilai dampak terhadap lingkungan hidup, d. Rehabilitasi sumber daya alam, dan e. Pendayagunaan wilayah dengan tidak merusak lingkungan hidup.

$\mathrm{Hal}$ ini berarti bahwa dalam pemanfaatannya perlu didasari oleh kebijakan dan upaya pengelolaan sumber daya alam yang rasional artinya pemanfaatan sumber daya alam dan lingkungan hidup harus seimbang dengan pelestariannya. Sumber daya alam merupakan penopang kehidupan penduduk yang perlu dijaga kelestariannya, karena kebutuhan pemenuhan tersebut akan terus berlanjut. Untuk melakukan pembangunan dengan memanfaatkan dan mengelola sumber daya alam, maka perlu ilmu pengetahuan dan teknologi yang tidak merusak ekosistem.

\section{b. Izin Lingkungan Sebagai Upaya Untuk Mewujudkan Tujuan Pembangunan Berkelanjutan}

Dalam implementasi Tujuan Pembangunan Berkelanjutan, terdapatbeberapaprinsipuntuk mendorong penerapan Tujuan Pembangunan Berkelanjutan di semua negara baik negara maju maupun negara berkembang. Salah satu prinsip yang diadopsi dan disepakati adalah prinsip integration. Prinsip ini mengandung makna bahwa pembangunan berkelanjutan dilaksanakan secara terintegrasi dan saling terkait pada semua dimensi sosial, ekonomi dan lingkungan. ${ }^{14}$ Oleh karena itu, setiap pembangunan ekonomi dan sosial harus memperhatikan dampak lingkungan dan mencegah kerusakan lingkungan.

Salah satu upaya untuk mewujudkan hal tersebut, maka setiap pembangunan diperlukan adanya izin lingkungan. Izin Lingkungan menurut Pasal 1 angka 1 Peraturan Pemerintah No. 27 Tahun 2012 adalah izin yang diberikan kepada setiap orang yang melakukan Usaha dan/atau Kegiatan yang wajib AMDAL atau Upaya Pengelolaan Lingkungan Hidup dan Upaya Pemantauan Lingkungan Hidup (UKL-UPL) dalam rangka perlindungan dan pengelolaan lingkungan hidup sebagai prasyarat memperoleh izin Usaha dan/atau Kegiatan. Izin lingkungan diterbitkan oleh Menteri, Gubernur, Bupati/ Walikota sesuai dengan kewenangannya.

Definisi AMDAL menurut Undang-Undang PPLH adalah kajian mengenai dampak penting suatu usaha dan/atau kegiatan yang direncanakan pada lingkungan hidup yang diperlukan bagi proses pengambilan keputusan tentang penyelenggaraan usaha dan/atau kegiatan. AMDAL adalah analisis yang meliputi berbagai macam faktor seperti fisik, kimia, biologi, sosial ekonomi, dan sosial budaya yang dilakukan secara menyeluruh yang terdiri dari 3 (tiga) dokumen, yaitu Kerangka Acuan, AMDAL dan Rencana Pengelolaan Lingkungan Hidup dan Rencana Pemantauan Lingkungan Hidup (RKL-RPL).

AMDALdiperlukanbagikegiatan usahayang berdampak penting bagi lingkungan hidup. Bagi kegiatan usaha yang tidak berdampak penting tetap memerlukan izin lingkungan yang disebut dengan Upaya Pengelolaan

\footnotetext{
13 Al. Sentot. Op.cit. hlm 6

14 Badan Pusat Statistik, Potret Awal Tujuan Pembangunan Berkelanjutan (Sustainable Development Goals) di Indonesia( Badan Pusat Statistik/Statistics Indonesia, 2016). hlm. 3.
} 
dan Upaya Pemantauan Lingkungan Hidup (UKL-UPL). UKL-UPL adalah pengelolaan dan pemantauan terhadap usaha dan/atau kegiatan yang tidak berdampak penting terhadap lingkungan hidup yang diperlukan bagi proses pengambilan keputusan tentang penyelenggaraan usaha.

Dalam Pasal 22 Ayat (2) Undang-Undang PPLH, dampak penting suatu usaha ditentukan berdasarkan kriteria sebagai berikut: a. Besarnya jumlah penduduk yang akan terkena dampak; b. Luas wilayah penyebaran dampak; c. Intensitas dan lamanya dampak berlangsung, d. Banyaknya komponen lingkungan hidup lain yang akan terkena dampak; e. Sifat kumulatif dampak; f. Berbalik atau tidak berbaliknya dampak; dan/atau g. Kriteria lain sesuai dengan perkembangan ilmu pengetahuan dan teknologi.

Tahapan kegiatan untuk mendapatkan Izin Lingkungan dijelaskan melalui skema berikut ini ${ }^{15}$ :

Gambar 1. Skema Proses Izin Lingkungan

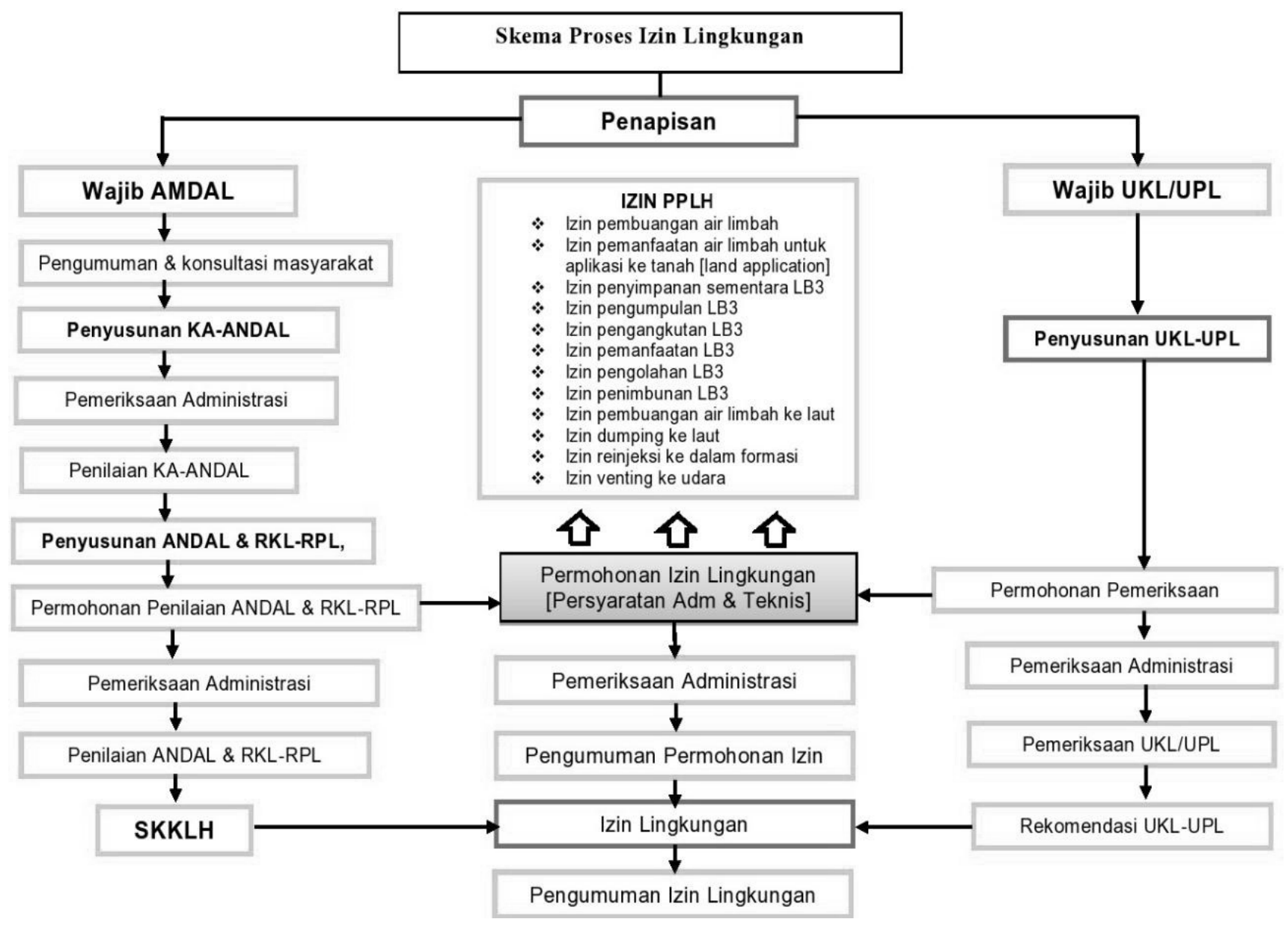

15 AL Sentot Sudarwanto, Op.cit, hlm. 44. 
Secara garis besar proses Izin Lingkungan adalah sebagai berikut :

a. Proses Penapisan (Screening)

Proses penapisan yaitu proses untuk menentukan apakah suatu rencana kegiatan industri atau kawasan industri dalam proses izin lingkungan wajib menyusun dokumen AMDAL atau UKLUPL. Ketentuan mengenai jenis usaha dan/atau kegiatan yang wajib dilengkapi dengan AMDAL dapat dilihat dalam Peraturan Menteri Negara Lingkungan Hidup (PerMenLH) Nomor 05 Tahun 2012 tentang Jenis Rencana Usaha dan/atau Kegiatan yang Wajib Memiliki Analisis Mengenai Dampak Lingkungan Hidup.

b. Proses Pengumuman

Setiap rencana kegiatan yang diwajibkan untuk membuat AMDAL wajib mengumumkan rencana kegiatannya kepada masyarakat sebelum pemrakarsa melakukan penyusunan AMDAL. Pengumuman dilakukan oleh instansi yang bertanggung jawab dan pemrakarsa kegiatan. Pemrakarsa dalam menyusun dokumen AMDAL wajib mengikutsertakan masyarakat. Pengertian masyarakat dalam Pasal 9 Peraturan Pemerintah No. 27 Tahun 2012 adalah masyarakat terkena dampak, masyarakat pemerhati lingkungan hidup dan masyarakat yang terpengaruh atas segala bentuk keputusan dalam proses AMDAL.

c. Penyusunan dan Penilaian Kerangka Acuan,

Kerangka Acuan dalam Pasal 1 angka 6 Peraturan Pemerintah No. 27 Tahun
2012 adalah ruang lingkup kajian analisis dampak lingkungan hidup yang merupakan hasil pelingkupan. Kerangka Acuan merupakan dasar dari penyusunan ANDAL dan RKL-RPL. Pelingkupan ${ }^{16}$ merupakan suatu proses untuk menemukan atau menetapkan dampak penting atau disebut pula sebagai masalah utama (main issue) dari suatu proyek terhadap lingkungannya.

d. Penyusunan dan Penilaian ANDAL dan RKL-RPL,

ANDAL adalah sebuah dokumen yang isinya tentang telaahan cermat terhadap dampak penting dari sebuah rancangan atau rencana kegiatan. Dampak-dampak penting yang sudah teridentifikasi di dalam dokumen Kerangka Acuan Ialu ditelaah dengan metodologi yang sudah disepakati.

Rencana Pengelolaan Lingkungan Hidup selanjutnya disebut RKL adalah upaya penanganan dampak lingkungan yang ditimbulkan dari rencana usaha dan/atau kegiatan. Rencana Pemantauan Lingkungan Hidup selanjutnya disebut RPL adalah upaya pemantauan komponen lingkungan hidup yang terkena dampak dari rencana usaha dan/atau kegiatan.

e. Persetujuan Kelayakan Lingkungan Berdasarkan berita acara Rapat Komisi, Ketua Komisi Penilai AMDAL (KPA) menyampaikan rekomendasi hasil penilaian akhir yang dilengkapi dengan konsep Surat Keputusan Kelayakan/ Ketidaklayakan Lingkungan Hidup kepada Menteri, Gubernur, atau Bupati/Walikota sesuai kewenangannya. Jangka waktu

16 Sudharto P Hadi, Dimensi Lingkungan Perencanaan Pembangunan (Yogyakarta : Gadjah Mada University Press, 2001), hlm. 45. 
penetapan SK Kelayakan/Ketidaklayakan Lingkungan Hidup dilakukan paling lama 10 hari kerja terhitung sejak diterimanya rekomendasi hasil penilaian oleh ketua KPA. Keputusan kelayakan lingkungan hidup suatu rencana usaha dan/atau kegiatan diterbitkan oleh:

1) Menteri, untuk dokumen yang dinilai oleh komisi penilai pusat;

2) Gubernur, untuk dokumen yang dinilai oleh komisi penilai provinsi; dan

3) Bupati/Walikota, untuk dokumen yang dinilai oleh komisi penilai kabupaten/ kota.

f. Permohonan dan Penerbitan Izin Lingkungan

Izin Lingkungan adalah izin yang diberikan kepada setiap orang yang melakukan usaha dan atau kegiatan yang wajib AMDAL atau UKL-UPL dalam rangka Perlindungan Dan Pengelolaan Lingkungan Hidup sebagai prasyarat memperoleh izin usaha dan/atau kegiatan. Permohonan penerbitan Izin Lingkungan dilakukan bersamaan dengan permohonan penilaian dokumen ANDAL dan RKL-RPL kepada Menteri, Gubernur dan atau Bupati/Walikota sesuai dengan kewenangannya.

Untuk rencana usaha dan/atau kegiatan yang tidak wajib AMDAL dan wajib UKL UPL proses izin lingkungannya adalah sebagai berikut :

1) Pemrakarsa mengajukan permohonan pemeriksaan formulir/draft dokumen UKLUPL kepada Menteri, Gubernur dan atau Bupati/Walikota sesuai kewenangannya c.q instansi Dinas Lingkungan Hidup Provinsi atau Kabupaten/Kota dimana lokasi rencana usaha dan atau kegiatan akan dilaksanakan. Pada tahap ini Pemrakarsa juga mengajukan permohonan izin lingkungan kepada Menteri, Gubernur dan atau Bupati/Walikota sesuai kewenangannya. Untuk sebagian wilayah diajukan kepada Badan Perijinan Terpadu dan Penanaman Modal Kabupaten Kota.

2) Tim Pemeriksa UKL UPL Dinas Lingkungan hidup Kabupaten/Kota melakukan pemeriksaan administrasi terhadap draft dokumen UKL-UPL, apabila tidak memenuhi ketentuan, Sekretariat menyerahkan kembali draft dokumen UKLUPL kepada Pemrakarsa untuk diperbaiki;

3) Apabila telah memenuhi persyaratan administrasi, Tim melaksanakan rapat Koordinasi pembahasan penilaian draft dokumen UKL-UPL yang dihadiri Pemrakarsa, Tim Teknis, Instansi tertentu dan tenaga ahli bila diperlukan;

4) Pemrakarsa berkewajiban memperbaiki dokumen berdasarkan Berita Acara dan Notulensi hasil rapat pembahasan penilaian draft dokumen UKL-UPL;

5) Bila penyempurnaan draft dokumen UKL-UPL telah selesai dan diserahkan ke sekretariat Tim Pemerikasa maka Sekretariat membuat draft surat rekomendasi UKL-UPL yang diajukan ke Kepala Dinas Lingkungan Hidup Kabupaten/ kota selaku Ketua Tim Pemeriksa Dokumen UKL-UPL;

6) Waktu yang dibutuhkan sejak pengajuan permohonan penilaian UKL-UPL (sah secara administrasi) hingga terbitnya surat rekomendasi UKL-UPL maksimal adalah14 (empat belas) hari kerja diluar waktu perbaikan oleh pemrakarsa/dokumen; 
Surat rekomendasi UKL-UPL lingkungan menjadi salah satu syarat pengajuan Izin Lingkungan. Dinas Lingkungan Hidup mengumumkan rencana permohonan izin lingkungan dari Pemrakarsa di lokasi rencana usaha dan/atau kegiatan. Melalui proses pengumuman, masyarakat dapat memberikan saran, pendapat dan tanggapan (SPT) yang disampaikan secara tertulis kepada pemrakarsa dan Menteri, gubernur, atau bupati/walikota sesuai dengan kewenangan. Saran, pendapat dan tanggapan dari masyarakat sekitar terhadap rencana usaha dan/atau kegiatan sebagai bahan pertimbangan untuk menetapkan rekomendasi UKL-UPL dan Izin Lingkungan. Selanjutnya Dinas Lingkungan Hidup Kabupaten/Kota mengumumkan Izin Lingkungan yang sudah terbit.

\section{Izin Lingkungan dalam Rancangan Undang-Undang Omnibus Law Cipta Lapangan Kerja Bertentangan dengan Tujuan Pembangunan Berkelanjutan}

Izin lingkungan dalam rancangan UndangUndang Omnibus Law Cipta Lapangan Kerja disederhanakan melalui penghapusan AMDAL. Langkah berani Pemerintah tersebut dilakukan sebagai bentuk penyederhanaan izin yang diharapkan dapat memudahkan investasi tanpa mengorbankan kualitas penataan ruang dan kualitas lingkungan.

Dalam Peraturan Pemerintah No. 24 Tahun 2018 tentang Pelayanan Perizinan Berusaha Terintegrasi Secara Elektronik, Izin Lingkungan juga disederhanakan. Berdasarkan PP tersebut, Izin lingkungan hanya berdasarkan komitmen dimana pelaku usaha dapat mendapatkan Izin Usaha dan Izin Lingkungan dengan komitmen akan melengkapi persyaratan lainnya kemudian. Artinya, pelaku usaha dapat melangsungkan kegiatan usahanya dengan melengkapi izin dikemudian hari.

Selain didalam Rancangan Undang-Undang Omnibus Law, penghapusan AMDAL dalam rangka penyederhanaan perizinan ditetapkan melalui Peraturan Menteri Lingkungan Hidup dan Kehutanan Republik Indonesia Nomor: P. 24/MENLHK/SETJEN/KUM.1/7/2018 tentang Pengecualian Kewajiban Menyusun Analisis Mengenai Dampak Lingkungan untuk Usaha dan/atau Kegiatan yang Berlokasi di Daerah Kabupaten/Kota yang telah memiliki Rencana Detail Tata Ruang (RDTR).

Dalam konteks izin lingkungan, RDTR tidak dapat menggantikan AMDAL sebagai dokumen lingkungan hidup. AMDAL dalam Pasal 1 angka 11 Undang-Undang PPLH adalah kajian mengenai dampak penting suatu usaha dan/atau kegiatan yang direncanakan pada lingkungan hidup, yang diperlukan bagi proses pengambilan keputusan tentang penyelenggaraan usaha dan/atau kegiatan. Didalam dokumen AMDAL terdapat fungsi pengelolaan terhadap lingkungan hidup diantaranya mencegah terjadinya pencemaran dan kerusakan lingkungan serta pemborosan sumber daya alam, menghindari timbulnya konflik dengan masyarakat dan kegiatan lain di sekitar lokasi rencana kegiatan, serta menjaga agar pelaksanaan pembangunan tetap sesuai dengan prinsip-prinsip pembangunan berkelanjutan dan berwawasan lingkungan. Jadi, sebagai langkah pencegahan terhadap dampak pencemaran dan kerusakan lingkungan, AMDAL merupakan suatu kajian dalam tahap perencanaan suatu rencana usaha dan/atau kegiatan. 
Berbeda dengan AMDAL, RDTR dalam Pasal 1 Peraturan Menteri Agraria Dan Tata Ruang/Kepala Badan Pertanahan Nasional Republik Indonesia Nomor 16 Tahun 2018 adalah rencana secara terperinci tentang tata ruang wilayah Kabupaten/Kota yang dilengkapi dengan ketentuan yang mengatur tentang persyaratan pemanfaatan ruang dan ketentuan pengendaliannya dan disusun untuk setiap blok/zona peruntukan yang penetapan zonanya dalam rencana detail tata ruang.

Artinya, didalam RDTR hanya mengatur soal zonasi atau peruntukan kawasan dan tidak secara spesifik mengatur mengenai detail suatu proyek, apalagi kewajiban pelaku usaha dalam pengelolaan lingkungan hidup seperti yang tertulis dalam dokumen AMDAL. RDTR tidak dapat menggantikan fungsi AMDAL sebagai rangkaian dari izin lingkungan.

AMDAL dan RDTR tidak bisa untuk disetarakan, RDTR berorientasi pada sebuah kebijakan publik, sementara AMDAL berorientasi pada proyek/kegiatan tertentu. AMDAL adalah instrumen pengendalian dampak lingkungan terhadap rencana kegiatan dalam skala tapak proyek. Sementara RDTR adalah instrumen pengendalian ruang berdasarkan tata guna lahan peruntukan pada skala regional. Untuk beberapa kegiatan dalam lingkup regional tidak bisa dijadikan satu untuk pengendalian lingkungannya, terlebih di daerah yang sudah padat, dimana daya dukung dan daya tampung lingkungannya sudah rendah.

AMDAL yang diganti dengan RDTR justru menyebabkan ketidakjelasan siapakah pihak yang bertanggung jawab atas pengelolaan lingkungan hidup. Tanpa adanya dokumen lingkungan hidup (AMDAL, UPL-UKL) pelaku usaha tidak memiliki kewajiban dalam pengelolaan lingkungan hidup. RDTR justru dapat menghambat investasi. Hal ini karena, investor merencanakan usahanya akan selalu memperhitungkan lokasi strategis, sedangkan lokasi sudah dikunci dengan RDTR.

Pembangunan yang cenderung hanya mengedepankan kepentingan ekonomi, tanpa mempertimbangkan izin lingkungan sebagai instrumen pencegahan justru dapat mengancam investasi yang sudah ada. Hasil kajian World Bank menyatakan bahwa buruknya pengelolaan lingkungan hidup menimbulkan dampak buruk terhadap perekonomian dan masyarakat miskin. Polusi dan pengelolaan limbah yang buruk membawa dampak negatif yang tinggi terhadap perekonomian Indonesia. Total kerugian ekonomi dari terbatasnya akses terhadap air bersih dan sanitasi, diestimasi, secara konservatif, adalah sebesar 2 persen dari PDB tiap tahunnya. Biaya yang timbul dari polusi udara terhadap perekonomian Indonesia diperkirakan sekitar 400 juta dollar setiap tahunnya. Biaya yang timbul akibat polusi udara di wilayah Jakarta saja diperkirakan sebanyak 700 juta dollar per tahunnya. ${ }^{17}$ Problematika tersebut justru menjadi beban baru bagi Pemerintah.

Penyederhanaan Izin Lingkungan dengan manghapuskan AMDAL bertentangan dengan Tujuan Pembangunan Berkelanjutan. Kondisi ini hanya menempatkan pembangunan dalam perspektif jangka pendek karena tidak

World Bank, Indonesia Policy Briefs - Ide-Ide Program 100 Hari (World Bank, 2015). 
mengaplikasikan lingkungan hidup kedalam pembangunan ekonomi. ${ }^{18}$ Disatu sisi, hukum yang mengatur tentang segi-segi lingkungan hidup haruslah bersifat antisipatif. ${ }^{19}$ Oleh karenaitu, Omnibus Lawyang sedang diusulkan Pemerintah seharusnya dapat mengantisipasi isu-isu lingkungan hidup dengan tetap mengusung spirit penyerderhanaan perijinan dalam prosedur izin lingkungan tanpa menghilangkan subtansi izin lingkungan. Izin lingkungan adalah formula strategis untuk mencapai Tujuan Pembangunan Berkelanjutan. ${ }^{20}$

Jepang sekelas negara maju saja masih memiliki Environment Impact Assesment (EIA), bagaimana dengan Indonesia yang dengan Omnibus Law justru mau menghapus AMDAL? Kenyataan yang sekarang dimana masih menerapkan kewajiban AMDAL saja masih terjadi pelanggaran, pada praktek pengelolaan dampak ada saja yang tidak mentaati kewajiban Pengelolaan Lingkungan hidup. Selain itu hambatan dari komisi penilai yang beda wilayah beda persepsi terkait penyusunan AMDAL, beberapa dokumen AMDAL hanya sebatas prosedur dan prasyarat administrasi saja, inilah yang harus dibenahi dengan penataan kelembagaan dan revolusi mental bagi para pemangku kepentingan perijinan.

Identifikasi akan faktor penyebab hambatan investasi perlu ditelaah dengan teliti dan cermat. Problematika penghambat investasi apakah di aspek subtansi perijinan atau proses perijinan. Itulah yang seharusnya dikonstruksikan dalam Omnibus Law. Kerangka subtansi Rancangan Undang-
Undang Omnibus Law Cipta Lapangan Kerja belum cukup untuk memenuhi terwujudnya pembangunan yang mempertimbangkan kesinambungan lingkungan hidup. Omnibus Law dikonstruksikan dengan penekanan pada eksploitasi bukan pada konservasi dan perlindungan. Identifikasi problematika perizinan lingkungan kurang diperhatikan dengan baik. Peran, tanggung-jawab, dan mekanisme koordinasi pada tingkat nasional dan daerah, misalnya, tidak digariskan dengan baik. Hal-hal ini menimbulkan hambatan yang signifikan terhadap kegiatan usaha dan pengelolaan lingkungan hidup secara efektif.

Omnibus Law yang sedang diusung saat ini justru bertolak belakang dengan komitmen Pemerintah untuk mewujudkan Tujuan Pembangunan Berkelanjutan yang tertuang dalam Peraturan Presiden No. 59 Tahun 2017 tentang Pelaksanaan Pencapaian Tujuan Pembangunan Berkelanjutan. Hal ini karena Pemerintah yang terlalu mengedepankan pembangunan ekonomi tanpa memperhatikan dampak lingkungan.

Omnibus Law tanpa memperhatikan lingkungan hidup dan menghapuskan izin lingkungan justru menempatkan pelaku usaha dalam ketidakpastian hukum. Kegiatan usaha pelaku usaha dapat sewaktu-waktu dapat ditutup apabila tidak melakukan pengelolaan lingkungan hidup dan menimbulkan pencemaran lingkungan. Kondisi ini tentunya bertolak belakang dengan spirit meningkatkan iklim investasi yang digalakkan pemerintah saat ini. Izin lingkungan adalah sarana bagi Pemerintah untuk melakukan deteksi dini dampak kegiatan usaha terhadap lingkungan

18 Sudharto P. Hadi, Op cit. hlm. 2.

19 Samsul Wahidin, Op cit. hlm 24.

20 AL. Sentot Sudarwanto, Op cit. hlm. 5. 
hidup dan pengawasan pemerintah terhadap kegiatan usaha.

\section{Penutup}

Izin lingkungan berfungsi sebagai instrumen pencegahan yang dapat membendung dampak negatif pembangunan ekonomi terhadap lingkungan hidup dan menjaga agar pelaksanaan pembangunan tetap sesuai dengan prinsip-prinsip pembangunan berkelanjutan dan berwawasan lingkungan. Oleh karena itu, Omnibus Law harus dapat menyederhanakan izin usaha dengan tetap memperhatikan lingkungan hidup.

Proses identifikasi hambatan berusaha perlu dikaji lebih komprehensif untuk menemukan faktor penghambat investasi apakah di aspek subtansi perizinan atau di aspek proses perizinan. Omnibus Law diharapkan senantiasa sejalan dengan komitmen Pemerintah untuk mewujudkan Tujuan Pembangunan Berkelanjutan. Kemudahan berusaha dengan menghapuskan izin lingkungan (termasuk AMDAL) justru menempatkan pelaku usaha dalam kondisi ketidakpastian hukum dan menghilangkan peran Pemerintah Pusat dan Daerah dalam pengawasan kegiataan usaha yang berdampak terhadap lingkungan hidup.

Penulis merekomendasikan agar AMDAL tetap dikonstruksikan dalam subtansi Undang-Undang Omnibus Law sebagai rangkaian izin lingkungan dan dokumen lingkungan hidup bagi setiap kegiatan usaha khususnya yang beresiko tinggi terhadap lingkungan hidup. Namun, pemerintah juga diharapkan dapat mengkonstruksikan proses perizinan lingkungan yang cepat, sederhana dan biaya yang memadai melalui rekonstruksi kelembagaan, konsistensi mekanisme penilaian dokumen AMDAL atau pemeriksaan dokumen UKL-UPL, pengawasan serta pemantauan dilakukan secara ketat dengan penambahan dan merevitalisasi Pejabat Pengawas Lingkungan Hidup Daerah (PPLHD).

\section{Daftar Pustaka}

\section{Buku}

Badan Pusat Statistik, Potret Awal Tujuan Pembangunan Berkelanjutan (Sustainable Development Goals) di Indonesia, (Badan Pusat Statistik/Statistics Indonesia, 2016).

Budiardjo, Eko dan Hardjohubojo, Sudanti, Kota Berwawasan Lingkungan (Bandung: Alumni, 1993).

Hadi, P. Sudharto, Dimensi Lingkungan Perencanaan Pembangunan, (Yogyakarta: Gadjah Mada University Press, 2001).

Hoelman, B. Mickael, Parlinggoman Parhusip, Bona Tua , Eko Sutoro, Bahagijo Sugeng, Santono Hamong, Panduan SDGs Untuk Pemerintah Daerah (Kota dan Kabupaten) (Jakarta: International NGO Forum on Indonesian Development, 2015).

Sudarwanto, AL. Sentot, AMDAL \& Proses Penyusunan (Berdasarkan Peraturan Menteri Lingkungan Hidup Nomor 16 Tahun 2012 Tentang Pedoman Penyusunan Dokumen Lingkungan Hidup) (Surakarta: UNS Press, 2018).

Wahidin, Samsul, Dimensi Hukum Perlindungan dan Pengelolaan Lingkungan Hidup (Yogyakarta: Pustaka Pelajar, 2014).

\section{Makalah/Artikel/Prosiding/Hasil Penelitian}

Alisjahbana, Salsiah. Armida, "Strategi indonesia Mewujudkan Pembangunan Berkelanjutan, Inklusif, dan Berkeadilan" (Makalah Disampaikan pada Konferensi INFID, Jakarta, 27 November 2013).

Asian Environmental Compliance and Enforcement Network, "Environmental Compliance and Enforcement in Indonesia Rapid Assessment", The Secretariat of Asian Environmental Compliance and Enforcement Network (2008). Indonesian Center for Environmental Law (ICEL), "Catatan Awal Tahun 2019: Narasi Yang Hilang 
Dalam Proyeksi Kebijakan Lingkungan Hidup Capres-Cawapres" (2019).

Kementrian Lingkungan Hidup dan Kehutanan, "Omnibus Law Cipta Lapangan Kerja" (Bahan Rapat Terbatas Kementrian Lingkungan Hidup, Bogor, 27 Desember 2019).

Taufik, Ade. Irawan, "Evaluasi Regulasi dalam Menciptakan Kemudahan Berusaha bagi UMKM, Jurnal Recht Vinding (2017).

World Bank, "Indonesia Policy Briefs - Ide-Ide Program 100 Hari" (World Bank, 2015).

\section{Peraturan}

Undang-Undang No. 32 Tahun 2009 tentang Perlindungan dan Pengelolaan Lingkungan Hidup

Peraturan Pemerintah No. 27 Tahun 2012 tentang Izin Lingkungan

Peraturan Pemerintah No. 24 Tahun 2018 tentang Pelayanan Perizinan Berusaha Terintegrasi Secara Elektronik
Peraturan Presiden No. 59 Tahun 2017 tentang Pelaksanaan Pencapaian Tujuan Pembangunan Berkelanjutan

Instruksi Presiden No. 7 Tahun 2019 Tentang Percepatan Kemudahan Berusaha

Peraturan Menteri Lingkungan Hidup Nomor 16 Tahun 2012 tentang Pedoman Penyusunan Dokumen Lingkungan Hidup

Peraturan Menteri Lingkungan Hidup Dan Kehutanan No. P.24/MENLHK/SETJEN/ KUM.1/7/2018 tentang Pengecualian Kewajiban Menyusun Analisis Mengenai Dampak Lingkungan untuk Usaha dan/atau Kegiatan yang Berlokasi di Daerah Kabupaten/ Kota yang telah memiliki Rencana Detail Tata Ruang (RDTR)

Peraturan Menteri Agraria Dan Tata Ruang/ Kepala Badan Pertanahan Nasional Republik Indonesia No. 16 Tahun 2018 Tentang Pedoman Penyusunan Rencana Detail Tata Ruang Dan Peraturan Zonasi Kabupaten/Kota dan berbagai regulasi yang terkait dengan lingkiungan hidup. 